\title{
Impact of the introduction of artificial intelligence on Russia's economic development under the pandemic conditions
}

\author{
Yu.V. Matveeva \\ Samara National Research University, Samara, Russian Federation \\ E-mail: dr.ymatveeva@ ssau.ru. ORCID: https://orcid.org/0000-0003-4755-226X \\ M.T. Chigwanda \\ Samara National Research University, Samara, Russian Federation \\ E-mail: marlvin.chigwanda@ gmail.com. ORCID: https://orcid.org/0000-0001-9707-6033 \\ V.P. Matveeva \\ Samara National Research University, Samara, Russian Federation \\ E-mail: matveevalera98@mail.ru. ORCID: https://orcid.org/0000-0002-1461-5968
}

\begin{abstract}
This article considers the general rise in the digitalization of various industries of countries around the world. A concrete study of the Russian Federation's artificial intelligence landscape pre-COVID-19, the reasons why various Russian industries and economic structures began integrating artificial intelligence on a large scale during the pandemic, and the different methods and ways in which artificial intelligence was actually integrated into various sectors of industry of the country during the COVID-19 pandemic is made. The outcome of that integration and its impact on the performance indicators of Russian businesses and the Russian economy is discussed. Special emphasis is placed on the outcome of the integration on the country's labor market. Finally, a look into the role of AI in the development of Russia's post-pandemic economic future is made, with special emphasis on the 2030 development objectives of the Russian Federation and the United Nation's 2030 Agenda for Sustainable Development.

Key words: artificial intelligence; COVID-19 pandemic; economic development; innovation; technological development; economic stability; high technology.

Citation. Matveeva Yu.V., Chigwanda M.T., Matveeva V.P. Impact of the introduction of artificial intelligence on Russia's economic development under the pandemic conditions. Vestnik Samarskogo universiteta. Ekonomika $i$ upravlenie = Vestnik of Samara University. Economics and Management, 2021, vol. 12, no. 2. pp. 123-131. DOI: http://doi.org/10.18287/2542-0461-2021-12-2-123-131.

Information on the conflict of interest: authors declare no conflict of interest.

(C) Matveeva Yu.V., Chigwanda M.T., Matveeva V.P., 2021

Yulia V. Matveeva - associate professor of the Department of Management and Organisation of Production, Samara National Research University, 34, Moskovskoye shosse, Samara, 443086, Russian Federation.

Marlvin T. Chigwanda - Master's degree student of the Department of Management and Organisation of Production, Samara National Research University, 34, Moskovskoye shosse, Samara, 443086, Russian Federation. Valeria P. Matveeva - Master's degree student of the Department of Economics, Samara National Research University, 34, Moskovskoye shosse, Samara, 443086, Russian Federation.
\end{abstract}

\section{НАУЧНАЯ СТАТЬЯ}

УДК 339.43 
Ю.В. Матвеева

Самарский национальный исследовательский университет имени академика С.П. Королева, г. Самара, Российская Федерация E-mail: dr.ymatveeva@ ssau.ru. ORCID: https://orcid.org/0000-0003-4755-226X

М.Т. Чигванда Самарский национальный исследовательский университет имени академика С.П. Королева, г. Самара, Российская Федерация E-mail: marlvin.chigwanda@gmail.com. ORCID: https://orcid.org/0000-0001-9707-6033

В.П. Матвеева

Самарский национальный исследовательский университет имени академика С.П. Королева, г. Самара, Российская Федерация E-mail: matveevalera98@mail.ru. ORCID: https://orcid.org/0000-0002-1461-5968

\begin{abstract}
Аннотация: В статье рассматривается и оценивается статус искусственного интеллекта в Российской Федерации до пандемии COVID-19, а также различные способы интеграции искусственного интеллекта в различные отрасли российской экономики в условиях пандемии COVID-19. Обсуждаются результаты этой интеграции и ее влияние на показатели деятельности российского бизнеса и российской экономики в целом. Сделан прогноз роли искусственного интеллекта в развитии постпандемического экономического будущего Российской Федерации с особым упором на цели Российской Федерации на период до 2030 года и Повестку ООН в области устойчивого развития на период до 2030 года.

Ключевые слова: искусственный интеллект; экономическое развитие; инновации; технологическое развитие; экономическая стабильность; высокие технологии.

Цитирование. Matveeva Yu.V., Chigwanda M.T., Matveeva V.P. Impact of the introduction of artificial intelligence on Russia's economic development under the pandemic conditions // Вестник Самарского университета. Экономика и управление. 2021. Т. 12, № 2. С. 123-131. DOI: http://doi.org/10.18287/25420461-2021-12-2-123-131.
\end{abstract}

Информация о конфликте интересов: авторы заявляют об отсутствии конфликта интересов.

(C) Матвеева Ю.В., Чигванда М.Т., Матвеева В.П., 2021

Юлия Валерьевна Матвеева - доцент кафедры менеджмента и организации производства, Самарский национальный исследовательский университет имени академика С.П. Королева, 443086, Российская Федерация, г. Самара, Московское шоссе, 34.

Марлвин Татенда Чигванда - магистрант кафедры менеджмента и организации производства, Самарский национальный исследовательский университет имени академика С.П. Королева, 443086, Российская Федерация, г. Самара, Московское шоссе, 34.

Валерия Павловна Матвеева - магистрант кафедры экономики, Самарский национальный исследовательский университет имени академика С.П. Королева, 443086, Российская Федерация, г. Самара, Московское шоссе, 34 .

\title{
Scientific novelty of study
}

The importance of this study lies in the analysis of why and how Russian businesses and organisations are currently shifting towards the integration of artificial intelligence and digital technologies in their economic activities. The economic benefit of this shift to businesses is a crucial factor affecting the volume of investments towards this field and, consequently, the growth of this industry and the Russian economy as a whole. A thorough understanding of this shift is also important in analysing the impact of the introduction of artificial intelligence on the Russian labour market and the different ways in which this impact is being mitigated for sustainability with respect to both businesses and the Russian workforce. Methodological solutions and recommendations for the sustainable development, integration and application of artificial intelligence in the Russian economy as of now are critical.

\section{Introduction}

The COVID-19 pandemic had a serious impact on the economic development of the Russian Federation. Since the first cases of coronavirus were reported in the Russian Federation at the end of January 2020, the economies of countries around the world and Russia in particular experienced a significant upheaval [1]. 
The subsequent measures that were introduced as a way to manage the pandemic, including quarantine regimes and social distancing, resulted in a significant transformation of the way in which business in general is conducted. While these measures certainly led to a serious economic recession [1], advancements in the development of Artificial Intelligence (hereinafter referred to as "AI") and its integration into various economic sectors of developed countries around the world consequentially affected the overall economic performances of those countries. Russia's integration of artificial intelligence in various business sectors was already significantly revolutionising the Russian economic landscape as early as 2017 . Thus, by the onset of the COVID-19 pandemic, Russia had already begun its journey towards full integration of high technologies and artificial intelligence into its economy. As such, a detailed study of that integration, with a particular emphasis on the COVID-19 period, and its expected impact on Russia's economic development for the near future is most relevant. In addition, Russia's objective to fully integrate high technologies into its economy by 2030 (Decree of the President of the Russian Federation No. 203 dated 9 May 2017 - Concerning the Strategy for the Development of the Information Society in the Russian Federation for 2017-2030), in line with the country's commitment to the United Nations 2030 Sustainable Development Agenda, requires a full understanding of how these ambitious goals were realised during the pandemic, how they continue to be realised, and how they will affect the country's economic standing overall compared to the rest of the developed world. This research will analyse the impact of the introduction of AI solutions during the COVID-19 pandemic period on Russian business operations and on the Russian economy as a whole.

\section{Main research work}

Artificial Intelligence, or AI, refers to a set of process and software solutions used in industry to achieve results that are similar or superior to the result of human intellectual activity, giving processes and software the ability to self-learn, and used to solve data-based applied problems. AI solutions are solutions that are used to implement one of four areas of artificial intelligence:

1) computer vision, which is the search, tracking and classification of objects and photo and video generation;

2) natural language processing, which is the understanding of written language and generation of written text;

3) speech recognition and synthesis, which is the transformation of speech into text, timbre analysis,tonality, sound generation;

4) recommendation systems and decision support systems for support in choosing a solution, profilebased user interest prediction [2].

The introduction of AI in business is aimedmainly at increasing unit revenue and lowering the unit production cost of any particular product. Prior to the COVID-19 pandemic, Russian businesses had already launched several projects for the development and integration of AI technologies in their operations, primarily internal business processes [2].

The rapid development and integration of AI in the Russian economic space began long before the COVID-19 pandemic in 2017. In a study conducted by Science Guide on the Russian AI landscape, it was established that in 2017, Russian AI-focused companies were still facing several challenges in the full integration of AI solutions in their business processes. Russia's position in terms of the strength of research into AI solutions was estimated to be $20^{\text {th }}$ from several researches conducted a year earlier in 2016. The startups in AI development in Russia faced challenges related to the lack of qualified available personnel. Interestingly, many experts in AI graduating from Russian institutions of higher learning were finding employment and applying their knowledge abroad in better-paying companies and organizations. In contrast, Russia's immigration policies by then were still somewhat unconducive for foreign experts to seek employment in Russia. The same problems were affecting AI startup, which would immediately relocate to greener pastures outside Russia where support for AI projects in terms of investors and government funding was better. When it came to Russian businesses themselves, there was still a reluctance on the part of business owners to switch to new fields of doing business, since not much progress had been made. Nevertheless, Russia still showed great prospects for AI and AI solutions development, and the experts and startups that stayed behind made significant inroad in the expansion of the field and the thawing of investor confidence [3]. 
Figure 1 below shows Russia's AI investor landscape as of 2017.

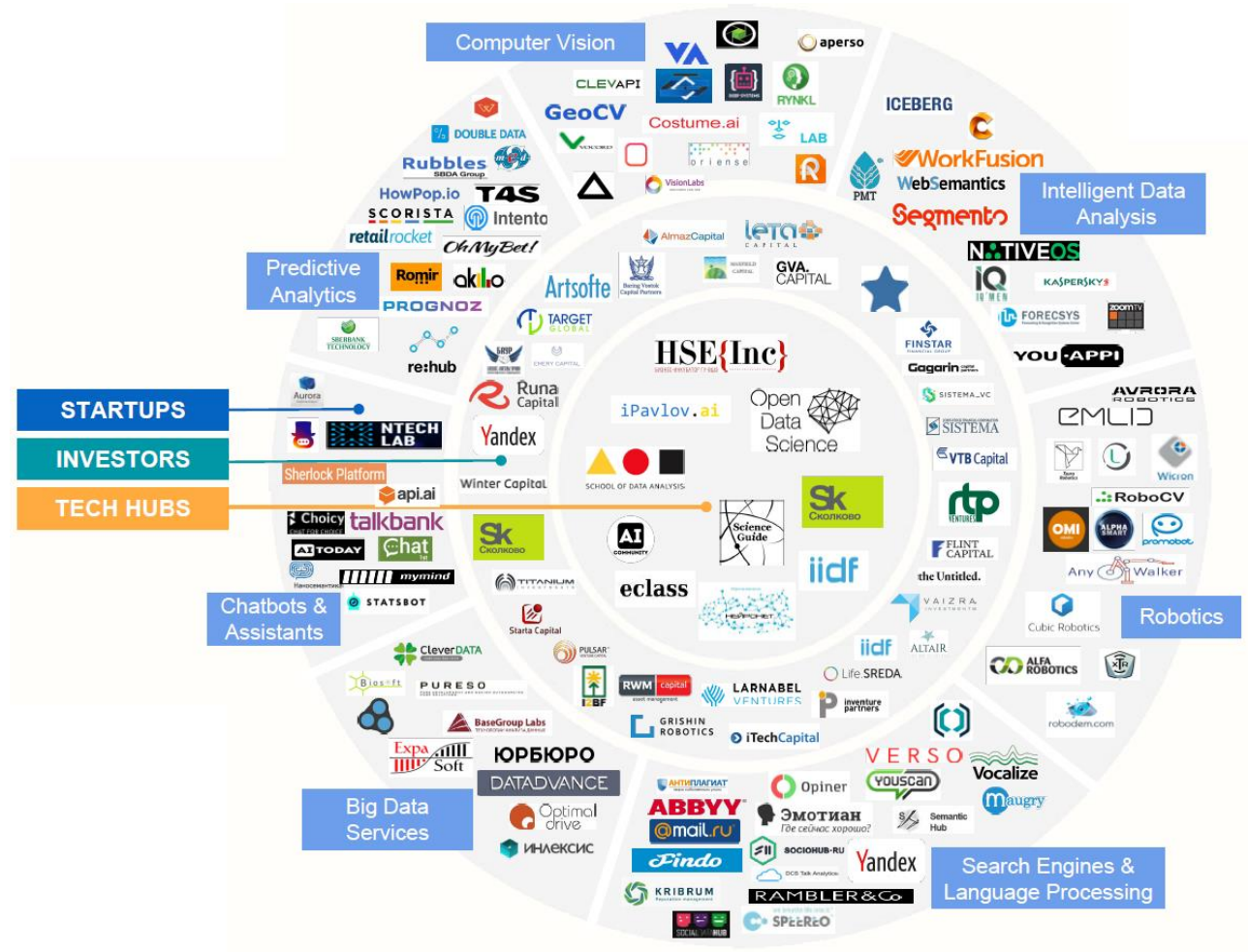

Figure 1 - Russian AI investors [Source: Science Guide]

It is clear from Figure 1 that as of year-end 2017, Russia was still lagging behind other global powers in terms of AI financing.

However, between 2017 and the start of the COVID-19 pandemic in January 2020, significant progress was achieved in AI and AI solutions development. According to the results of a survey conducted by Rostelecom that involved 100 of the largest companies in Russia, including foreign enterprises operating in Russia, the primary economic sectors that benefited directly from the introduction of AI technologies by the year 2021 in Russia are:

1) E-commerce

2) Financial management

3) Retail

4) Agriculture

5) Manufacturing

6) FMCG (Fast-moving consumer goods)

7) Telecommunications

8) Transport and logistics

9) Education, and

10) Public health [2].

In terms of the extent of implementation, the survey revealed that at the end of 2020, more than $85 \%$ of the major organizations operating in the Russian Federation were using AI solutions to some extent to optimize their internal business processes. These organizations were mainly in the financial sector, telecom, retail, IT, industry, and the oil and gas industry. Companies not yet using AI solutions by the end of 2020, mainly in manufacturing, banking and retail, expressed the reason as their lack of understanding of the benefits of AI solutions and the possible low profits. However, with more than $60 \%$ of these organizations having announced their plans for the implementation of AI solutions in their internal business processes, a surge is expected in the utilization of AI solutions by Russian businesses overall [2].

With this in view, it is important to note how the COVID-19 pandemic has accelerated the rate of implementation of AI solutions in the Russian economic space. In a Russia-China online business mission that was 
conducted at the height of the pandemic on 25 November 2020 between Chinese higher institutions of learning, technology platforms and high-tech companies (Zhongguancun Science and Technology Park, or China's Silicon Valley, Beijing Academy of Artificial Intelligence, DiDi company) and Russian technology platforms (Skoltech, Skolkovo Foundation) with the Chinese Embassy in Moscow, existing opportunities in the AI field having the potential of further strengthening the bilateral ties between Russia and China were discussed. The closed meeting was followed by an open webinar dedicated to Russian technology firms planning to conduct business in China. The participating Russian startups QBoard, Navigine, Agora Freight, Botkin AI, AIMED, Medical Screening Systems, and Siberia offered several AI solutions, including quantum computing for application in optimization processes, integrated positioning technologies for multiple industries, an online IT platform for freight, a software-based platform for radiological images analysis based on AI technologies, a mobile application for remote detection of malignant skin disease using neural networks, a medical decision support system based on neural network algorithms, and a radiology quality control system powered using AI-methods [4].

Figure 2 below shows the level of financing of AI in Russia, China and the USA.

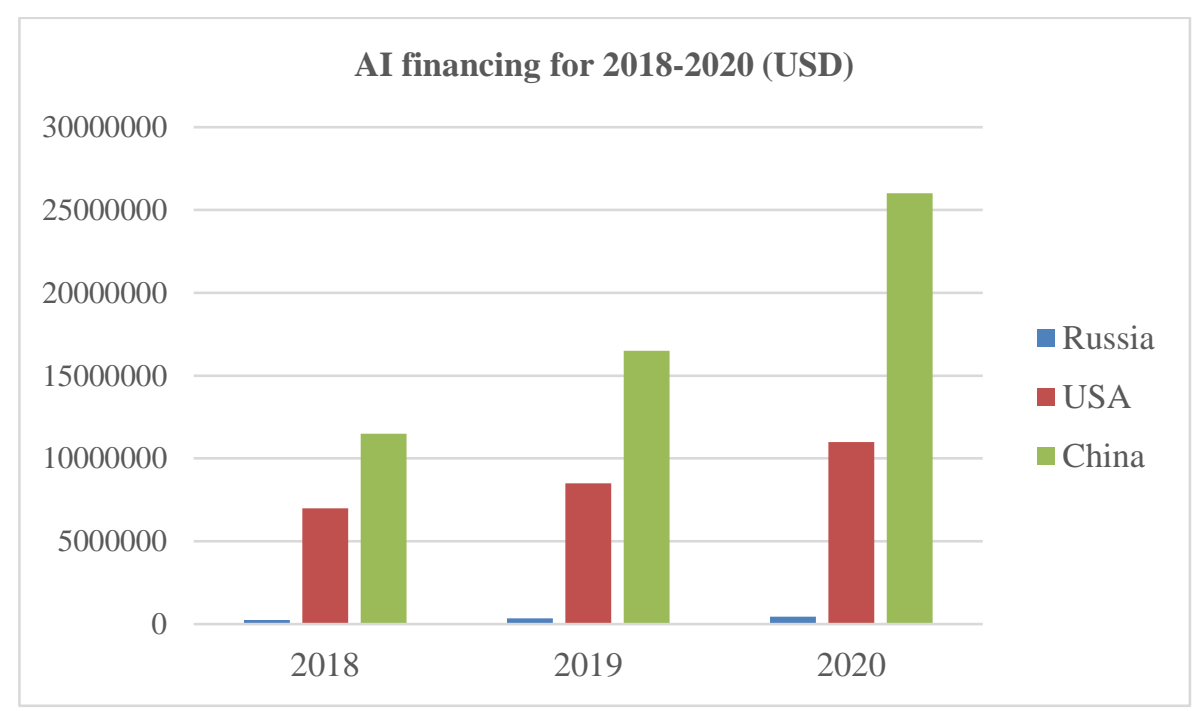

Figure 2 - Level of financing of AI in Russia, China and the USA [5]

Information provided by the IDC Worldwide Artificial Intelligence Extending Guide and published on TAdviser in early 2021 showed that Russia's AI market had reached USD 291 million by 2020, with spending on $\mathrm{AI}$ and AI solutions by government bodies and businesses having increased by $22.4 \%$ compared to 2019. The remarkable performance by AI-focused companies in the pandemic conditions was achieved partly because digital alternatives employing AI and AI solutions helped businesses adapt to the harsh economic realities of COVID-19. In these conditions, companies that had already made investments in AI and AI solutions began expanding their businesses accordingly, while those that had been reluctant to integrate AI AND AI solutions into their businesses began to appreciate the benefits of artificial intelligence in everyday business operations. For instance, Russian supermarkets that had been lagging behind in terms of implementing self-service points of sale now fully embraced the solutions to promote measures like social distancing. They also began employing artificial intelligence for customer service products like chat boxes and digital product recommendations to boost customer loyalty and generate additional revenue under the difficult economic conditions. The data also showed the financial sector remaining the biggest consumer of AI and AI solutions on the Russian market. Technologies for fraud detectionand analysis were introduced across different sectors of the financial services market. There were major investments in the development of digital assistants employing artificial intelligence and digital products to provide contactless customer service solutions remotely to clients. As for the manufacturing sector, various processes including product quality assurance, production optimisation, preventive maintenance and others began to adapted for the digital economy and artificial intelligence. 
Russian government organisations began to invest significantly in AI and AI solution from the beginning of 2020. The projected average rate of investment is $26.4 \%$ until 2024. The passed in the Presidential Decree No. 204 dated 7 May 2018, Russia is now focused on achieving sustainable scientific, technological and social and economic development through the implementation of technological innovations and support for companies and organisations engaged in technological development projects [4]. On 14 October 2019, 1prime announced thatthe Ministry of Digital Development, Communications and Mass Media of the Russian Federation made a projection that the market of artificial intelligence in the Russian Federation would grow 80 times by 2024 [6]. In terms of development, a state programme in the field of the development of AI and AI solutions was established in December 2019 [5]. State-run organisations are now highly interested in making investments in the application of AI and AI solutions for infrastructure development and digital services provided to citizens of the country [8]. The integration of AI and AI solutions in Russia's health sector led to the development and application of AI-based diagnostic and treatment systems, with digital assistants now available to process patients' requests and provide required information. AI growth in the health sector is projected to continue at an average annual rate of $40 \%$ for the next few years [5].

Nevertheless, as Figure 2 clearly shows, Russia still lags behind other countries in the development of AI and AI solutions. China - the country with the biggest investments in AI and AI solutions in the world, is reported to spend 350 times more than Russia on digital technology and artificial intelligence. The United States is also recognised as a leader in digital technologies and artificial intelligence, and its investments in the field still far surpass that of the Russian Federation. It can therefore be stated that Russia needs to increase its funding for $\mathrm{AI}$ and AI solutions projects and scientific research into artificial intelligence in order to catch up with the rest of the developed world [9].

The table below shows the growth in the volume of AI investments and the major highlights from 2017 to April 2021.

In the educational sector, on 5 December 2020, TASS reported that the Russian major bank Sberbank had announced plans to open in January 2021 the first non-profit academic institute in Russia focused on interdisciplinary research in artificial intelligence and its application [11]. The quarantine measures introduced because of the pandemic moved education to virtual. The accelerated development of virtual learning platforms allowed educational institutions and colleges to shift their activities from the classroom to online learning. Virtual classroom software like Big Blue Button became popular or mandatory. On 25 November 2020, Moscow School of Management SKOLKOVO announced that it had opened its second Classroom multimedia virtual educational platform. Driven by the growing demand for online education, the emergence to which the coronavirus pandemic played a pivotal role, Glassrum Ural is expected to allow the institution to transfer learning from offline to online while maintaining direct contact between the instructor and the students in a high-visual-quality space [12].

\section{Results and discussion}

Following their active integration of AI solutions into their business operations during the COVID-19 pandemic, many Russian companies have achieved significant results. The survey by Rostelecom [1] reported that more than $70 \%$ of AI-integrated companies in Russia are reaping direct financial benefits. More specifically, the cumulative financial benefit enjoyed by the surveyed companies amounted to about RUB 6 billion. Most of the companies reported from $0.1 \%$ to $1 \%$ of revenue from the integration of AI solutions. As the integration of AI solutions in Russian businesses continues to grow every year, as of now, more than $85 \%$ of companies have already integrated AI in their internal business operations with a focus on optimising profits and minimising costs per unit product. The average number of data scientists in companies that have benefited most from the integration of AI solutions in their internal business processes is between 30 and 100 employees, and $9 \%$ of the companies reported that their integration of AI solutions did not lead to any employees losing their jobs. An important segment of AI-integrating companies in Russia is that occupied by companies who are integrating their own solutions, which makes up about $50 \%$ of all the companies. Companies who use third-party solutions take advantage of both Russian-developed and foreign solutions in equal measure. A third of the surveyed companies develop AI solutions, primarily recommender systems and decision-making support systems, for other companies. Overall, the total sales of the AI solutions 
for all the companies amounted to about RUB 6 billion, which is comparable to the market for solutions developed by specialised AI developers or vendors. The survey also established that the factors limiting the full integration of AI solutions in Russian businesses include a poor understanding of the economic benefits of the integration of $\mathrm{AI}$ into internal business processes and the associated reduction in production costs $[2 ; 13]$.

Table - Growth in Russia's volume of AI investments and the major highlights from 2017 to April 2021

\begin{tabular}{|c|c|c|}
\hline Year & Highlight & $\begin{array}{l}\text { Investment } \\
\text { Volume }\end{array}$ \\
\hline 2017 & TAdviser research: AI market volume and development forecast & $\begin{array}{c}>\text { RUB } 100 \\
\text { million }\end{array}$ \\
\hline 2018 & $\begin{array}{l}\text { Russian AI technologies market reaches RUB } 2 \text { billion - the Ministry of } \\
\text { Telecom and Mass Communications } \\
\text { TAdviser Review: Artificial Intelligence } 2018 \\
\text { How Artificial Intelligence is Improving - Main Trends and Obstacles } \\
\text { Projection: By } 2021 \text {, the volume of the AI market in industry in Russia } \\
\text { will be USD } 380 \text { million } \\
\text { Artificial intelligence is the hottest topic of the Russian IT market }\end{array}$ & $\begin{array}{l}\text { RUB } 2 \\
\text { billion }\end{array}$ \\
\hline 2019 & $\begin{array}{l}\text { AI investments reach USD } 172.5 \text { million - IDC } \\
\text { Rosstandart approves the first standards in the field of AI } \\
\text { A consortium of developers of electronics and hardware systems for AI } \\
\text { is created in Russia } \\
\text { VTsIOM: Half of Russian business does not want to implement artifi- } \\
\text { cial intelligence } \\
\text { Market growth by } 48.2 \% \text { to USD } 139.3 \text { million - IDC } \\
\text { Approval by the President of the Russian Federation of the National } \\
\text { Strategy for AI Development Until } 2030 \\
\text { Main event: Creation of a Technical Committee for AI Standardization } \\
\text { Most common types of AI solutions in Russia are named } \\
30 \% \text { of Russian executives are actively implementing artificial intelli- } \\
\text { gence }\end{array}$ & $\begin{array}{l}\text { USD } 172.8 \\
\text { million [10] }\end{array}$ \\
\hline 2020 & $\begin{array}{l}\text { Market size exceeds USD } 290 \text { million } \\
\text { China spends } 350 \text { times more on AI than Russia } \\
\text { Research: Penetration of Artificial Intelligence Solutions in Russian } \\
\text { Companies } \\
\text { Plan for preparing AI standards is developed in Russia } \\
\text { Concept of legal regulation of AI and robotics has been created } \\
\text { Objectives of the concept: Industry-wide Regulation Tasks } \\
\text { Sectoral Regulation and Financial Incentives }\end{array}$ & $\begin{array}{l}\text { USD } 290 \\
\text { million }\end{array}$ \\
\hline 2021 & $\begin{array}{l}\text { Russia proposes to regulate the artificial intelligence market } \\
\text { Federal agencies in Russia began to implement AI - Deputy Prime } \\
\text { Minister Dmitry Chernyshenko } \\
\text { Podcast: Trends in Artificial Intelligence Solutions in } 2021\end{array}$ & $\begin{array}{l}\text { USD } 300 \\
\text { million }\end{array}$ \\
\hline
\end{tabular}

\section{Conclusion}

The integration of AI solutions and high technologies by Russian companies during the COVID-19 pandemic had a significant impact on business performance and cost reduction. Moving forward towards achievement of the United Nations 2030 Sustainable Development Goals, AI will increasingly become an important part of the business process. AI allows to do more with less, and its impact in reducing production costs in any organisation cannot be overstated. However, the rise of AI carries with it a real risk of the phasing out of human capital, and companies planning to use AI as one of their core business solutions must 
think seriously on how they are going to mitigate the loss of jobs on the part of their valued workers, which can be accomplished through the development of a knowledge economy.

\section{References}

1. Aganbegyan A.G., Klepach A.N., Porfiryev B.N., Uzyakov M.N., Shirov A.A. Post-Pandemic Recovery: The Russian Economy and the Transition to Sustainable Social and Economic Development. Studies on Russian Economic Development, vol. 31, pp. 599-605. DOI: http://doi.org/10.1134/S1075700720060027.

2. PJSC Rostelecom effects from the implementation of solutions based on artificial intelligence in Russian companies, pp. 3-15. Available at: https://www.company.rt.ru/press/news/files/ROSTELECOM_AI_0112.pdf. (In Russ.)

3. Skolkovo AI Companies Pitch Solutions to Chinese Representatives. Available at: https://sk.ru/news/skolkovoai-companies-pitch-solutions-to-chinese-representatives (accessed 05.03.2021).

4. Sberbank plans to open Russia's first AI institute. TASS. Russian News Agency. Available at: https://tass.com/economy/1230907 (05.03.2021).

5. SKOLKOVO Business School opens its second Glassroom. Available at: https://www.skolkovo.ru/news/ biznes-shkola-skolkovo-otkryla-svoj-vtoroj-glassrum (accessed 05.03.2021). (In Russ.)

6. Artificial Intelligence in Russia Landscape Overview 2017 First Edition. Available at: http://analytics.dkv.global/data/pdf/Extended-AI-in-Russia-Landscape-Overview.pdf (accessed 05.03.2021).

7. Artificial Intelligence (Russian market). TADVISER Available at: https://tadviser.com/index.php/Article: Artificial_Intelligence_\%28Russian_market\%29 (accessed March 05, 2021).

8. Vladimir Mitin. 16 April 2021. China spends 350 times more on AI than Russia. ITWeek. Available at: https://www.itweek.ru/ai/article/detail.php?ID=217907 (accessed 05.03.2021). (In Russ.)

9. Russian companies invest more than USD 170 million in AI. COMNEWS. 13.04.2020. Available at: https://www.comnews.ru/content/205551/2020-04-13/2020-w16/rossiyskie-kompanii-investirovali-ii-bolshe-170mln (accessed 05.03.2021).

10. The President of the Russian Federation approves a strategy for the development of artificial intelligence. PLUS Journal. Available at: https://plusworld.ru/daily/tehnologii/prezident-rf-utverdil-strategiyu-razvitiyaiskusstvennogo-intellekta $/$ ?utm_campaign $=$ plas-daily-102019\&utm_source $=$ sendpulse\&utm_medium $=$ email (05.03.2021). (In Russ.)

11. FTS begins to use artificial intelligence to work with individuals. Kommersant, 23.11.2017. Available at: https://www.kommersant.ru/doc/3475827 (accessed March 07, 2021). (In Russ.)

12. Ministry of Digital Development, Communications and Mass Media of the Russian Federation: Market of artificial intelligence in the Russian Federation by 2024 will grow 80 times. PRIME: Business News Agency. Available at: https://1 prime.ru/state_regulation/20191014/830402970.html. (accessed 05.03.2021). (In Russ.)

13. Chirkunova E., Anisimova V.Y., Tukavkin N.M. Innovative Digital Economy of Regions: Convergence of Knowledge and Information. Lecture Notes in Networks and Systems, 2021, vol. 133, pp. 123-130. DOI: http://doi.org/10.1007/978-3-030-47458-4_15.

\section{Библиографический список}

1. Aganbegyan A.G., Klepach A.N., Porfiryev B.N., Uzyakov M.N., Shirov A.A. Post-Pandemic Recovery: The Russian Economy and the Transition to Sustainable Social and Economic Development. // Studies on Russian Economic Development, vol. 31, pp. 599-605. DOI: http://doi.org/10.1134/S1075700720060027.

2. Эффекты ПАО «Ростелеком» от внедрения решений на основе искусственного интеллекта в российских компаниях. C. 3-15. URL: https://www.company.rt.ru/press/news/files/ROSTELECOM_AI_0112.pdf.

3. Skolkovo AI Companies Pitch Solutions to Chinese Representatives. URL: https://sk.ru/news/skolkovo-aicompanies-pitch-solutions-to-chinese-representatives (дата обращения: 05.03.2021).

4. Sberbank plans to open Russia's first AI institute. // TASS. Russian News Agency. URL: https://tass.com/economy/1230907 (дата обращения: 05.03.2021)

5. Бизнес-школа СКОЛКОВО открыла свой второй Глассрум. URL: https://www.skolkovo.ru/news/biznesshkola-skolkovo-otkryla-svoj-vtoroj-glassrum (дата обращения: 05.03.2021). 
6. Artificial Intelligence in Russia Landscape Overview 2017 First Edition. Science Guide. URL: http://analytics.dkv.global/data/pdf/Extended-AI-in-Russia-Landscape-Overview.pdf (дата обращения: 05.03.2021).

7. Artificial Intelligence (Russian market). // TADVISER. URL: https://tadviser.com/index.php/Article:Artificial_ Intelligence_\%28Russian_market\%29 (дата обращения: 05.03.2021).

8. Владимир Митин. 16 апреля 2021. Китай тратит на ИИ в 350 раз больше, чем Россия. // ITWeek. URL: https://www.itweek.ru/ai/article/detail.php?ID=217907 (дата обращения: 05.03.2021).

9. Российские компании инвестировали в ИИ больше $\$ 170$ млн // Новости цифровой трансформации, телекоммуникаций, вещания и ИТ. COMNEWS. 13.04.2020. URL: https://www.comnews.ru/content/205551/ 2020-04-13/2020-w16/rossiyskie-kompanii-investirovali-ii-bolshe-170-mln (дата обращения: 7 марта 2021).

10. Президент РФ утвердил стратегию развития искусственного интеллекта // Журнал ПЛАС. URL: https://plusworld.ru/daily/tehnologii/prezident-rf-utverdil-strategiyu-razvitiya-iskusstvennogo-intellekta/?utm_ campaign=plas-daily-102019\&utm_source=sendpulse\&utm_medium=email (дата обращения: 05.03.2021).

11. ФНС начала использовать искусственный интеллект для работы с физлицами. // Коммерсант. 23.11.2017. URL: https://www.kommersant.ru/doc/3475827 (дата обращения: 05.03.2021).

12. Минкомсвязь: Рынок искусственного интеллекта в РФ к 2024 году вырастет в 80 раз. // ПРАЙМ: Агентство экономической информации. URL: https://1 prime.ru/state_regulation/20191014/830402970.html. (дата обращения: 05.03.2021).

13. Chirkunova E., Anisimova V.Y., Tukavkin N.M. Innovative Digital Economy of Regions: Convergence of Knowledge and Information // Lecture Notes in Networks and Systems 2021. Vol. 133. P. 123-130. DOI: http://doi.org/10.1007/978-3-030-47458-4_15. 